[4] S. Zhukovetska/ Air flowing spatial modeling and simulation with SOLIDWORKS CAD. Zeszyty Naukowe Wydziału Elektroni-ki i Informatyki. Nr 13. POLITECH-NIKA KOSZALIŃ-SKA. - KOSZALIN, 2018. - C. 79-88.

\title{
References
}

[1] A.A. Alamovsky. SolidWorks 2007/2008. Computer modeling in engineering practice / A.A. Alyamovsky, A.A. Sobachkin, E.V. Odintsov, A.I. Kharitonovich. - SPb .: BHV-Petersburg. 2008 .-- 1040 p.: Ill.

[2] A. A. Alyamovsky. SolidWorks Simulation. How to solve practical problems. - SPb .: BHV- Petersburg. 2012 . - 448.

[3] Flow Simulation $2009 \quad$ Tutorial. [Electronic $\quad$ resource]. $\quad$ Access mode https://learn.ztu.edu.ua/pluginfile.php/29485/mod_resource/content/1/solidworks_flow_simulation_2009_tutorial.pdf.

[4] S. Zhukovetska / Air flowing spatial modeling and simulation with SOLIDWORKS CAD. Zeszyty Naukowe Wydziału Elektroni-ki i Informatyki. Nr 13. POLITECH-NIKA KOSZALIŃ-SKA. - KOSZALIN, 2018.-- S. 79-88.

\section{ДОСЛІДЖЕННЯ ТЕМПЕРАТУРНИХ ПОЛІВ В ПРОЦЕСІ ФОРМУВАННЯ ВУГЛЕЦЕВИХ ВИРОБІВ В РЕЖИМІ ПРЕСУВАННЯ}

\author{
Жученко О. А. ${ }^{1}$, Хібеба М. Г. \\ ${ }^{1,2}$ Національний технічний університет України «Київський політехнічний інститут імені Ігоря Сікорського», м. Київ, \\ Україна \\ ORCID: ${ }^{1} 0000-0001-5611-6529,{ }^{2} 0000-0003-0703-4820$ \\ E-mail: ${ }^{1}$ azhuch@ukr.net, ${ }^{2}$ hibeba19@gmail.com
}

Copyright (C) 2018 by author and the journal "Automation of technological and business - processes.

This work is licensed under the Creative Commons Attribution International License (CC BY).

http://creativecommons.org/licanses/by/4.0

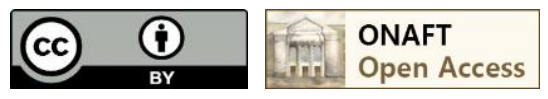

DOI:

\section{Анотація.}

Було проведено аналіз існуючих досліджень процесу формування вуглецевих виробів. Визначено, щзо поза увагою авторів залишається дослідження впливу таких технологічних параметрів, як потужність нагрівачів, температура завантаженої маси та швидкості пресування на температурні поля робочого простору мундштука гідравлічного пресу. В даній праці було досліджено зміну температурного поля в залежності від таких технологічних параметрів: потужності індукторів формувальної та калібрувальної зони мундштука, свічок для додаткового нагріву мундштука, температури поверхні масного циліндру та швидкості пресування. Оскільки для отримання бездефектної продукції необхідно, щуоб кожен з нагрівачів забезпечував заданий (такий, ще забезпечить умови проковзування) розподіл температур в своїи зоні мундштука, то також було досліджено динаміку температур в точках, щзо характеризують розподіл температур в кінці кожної зони мундштука (переріз наприкінці калібрувальної зони - I переріз, переріз на межі формувальна - калібрувальна зона - II переріз, переріз на межі масний циліндр формувальна зона - III переріз). В результаті досліджень, проведених за допомогою розробленої моделі виявлено, щзо найбільший вплив на температури в зонах I-II має індуктор калібрувальної зони. Також індуктор формувальної зони має значний вплив на температурне поле в III та II зонах, а свічки на температури в I та II зоні. При иьому вплив нагрівачів на більш віддалені зони проявляється тільки за 20-30 хв. після зміни потужності нагрівача, що свідчить про появу запізнювання в перехідному прочесі. Температура завантаженої маси має досить значний вплив на розподіл температур в усьому об'ємі робочого простору мундштука. Також виявлено, шэо збільшення швидкості пресування негативно впливає на середню температуру електродної маси, а також збільшує градієнт температур від иентральної частини робочого простору мундштука до його меж.

Abstract.

An analysis of existing forming carbon products studies has been carried out. It has been determined that the effect of such technological parameters as heaters power, loaded mass temperature and pressing speed on the hydraulic press mouthpiece working space temperature fields remains out of the authors' attention. In this paper, the variation of the temperature field was 
investigated depending on the following technological parameters: mouthpiece molding and calibration zone inductors power, candles for mouthpiece additional heating power, mass cylinder surface temperature and pressing speed. Since, to obtain nondefective products, it is necessary for each heaters to provide a predetermined (such as to provide slip conditions) temperatures distribution in its mouthpiece area, temperatures dynamics at the points characterizing the temperature distribution at the end of each mouthpiece zone (cross section at the end of the calibration zone - I cross section, cross section on the border forming - calibration zone - II cross section, cross section on the border of the mass cylinder - forming zone - III cross section) was also investigated. As results of the researches carried out with the help of the developed model, the calibration zone inducer has the greatest influence on the temperatures in zones I-II. Also, the molding zone inductor has a significant effect on the temperature field in the III and II zones, as well as candles on the temperatures in the I and II zones. In this case, heaters influence on more remote areas is manifested only in 20-30 minutes after changing the heater power, indicating the appearance of a delay in the transition process. The loaded mass temperature has a considerable influence on the temperature distribution throughout the mouthpiece working space volume. It has also been found that increasing the pressing speed negatively affects the average temperature of the electrode mass and also increases the temperature gradient from the mouthpiece working space center to its limits.

Ключові слова: виробництво вуглецевих виробів, формування вуглецевих виробів, гідравлічний прес, електродна маса, екструзія.

Keywords: carbon products production, carbon products formation, hydraulic press, electrode mass, extrusion.

\section{Вступ}

Одним з основних технологічних процесів виробництва вуглецевих виробів є формування останніх шляхом продавлювання електродної маси через мундштук відповідної форми у гідравлічному пресі, бо саме на етапі пресування електродних заготовок закладаються в основному всі спадкові властивості, що визначають якість готових виробів $[1,2]$. Зокрема, пресування в значній мірі визначає форму заготовки, іiі довжину, пористість та механічну міцність. Тому задача підвищення ефективності даного процесу є дуже актуальною і в сучасних умовах може бути розв'язана шляхом як розробки комплексу технічних і технологічних заходів з модернізації технології так і створення ефективної системи оптимального керування даним процесом. Важливою науковою задачею, яка постає в даному випадку є дослідження технології на основі розвитку наукових уявлень про даний процес.

\section{Аналіз літературних даних та постановка проблеми}

На даний момент існує велика кількість праць, присвячених як процесу екструзії [3-7] так і дослідженню властивостей вуглецевих виробів [8-11], але питання моделювання процесу формування вуглецевих виробів розглядається доволі рідко. Тому доцільним буде аналізувати й моделі процесів, що мають схожі фізико-хімічні основи та конструкційні особливості апаратів.

У працях [3-6] детально розглянуто теоретичні засади екструзії полімерів. Не дивлячись на те, що для опису даних процесів використовуються рівняння руху, нерозривності та енергії, за допомогою яких можна описати й формування вуглецевих заготовок представлені в даних роботах моделі не доцільно використовувати як основу в створенні математичної моделі формування вуглецевих заготовок, адже в них розглядається екструзія саме полімерів (тобто не враховуються особливості вуглецевих матеріалів). До того ж здебільшого розглядається екструзія полімерних матеріалів за допомогою черв'ячних пресів, тоді як формування вуглецевих заготовок відбувається видавлюванням електродної маси через мундштук за допомогою плунжера.

Процес формування через мундштук розглянуто в роботі [7]. В ній на базі класичних рівнянь ізотермічної напірної течії двох реологічно різних в'язкопластичних середовищ, що не змішуються в циліндричному каналі та підкорюються закону Оствальда-де-Віля, синтезована модель течії двох таких середовищ в формувальному каналі екструдера при коекструзії. Не дивлячись на те, що розглядається процес формування через мундштук використання даної моделі в якості основи для моделювання процесу формування вуглецевих виробів має ряд недоліків. По-перше, дана модель розглядає екструзію жировітамінної начинки та екструдата, отриманого на основі зернових, тобто проблема 3 врахування особливостей вуглецевих матеріалів не зникає. По-друге, на відміну від процесу формування вуглецевих виробів в даному процесі має місце коекструзія різних середовищ.

В роботі [8] розглядається модель руху не ньютонівських в'язкопластичних рідин, до яких відноситься електродна маса (матеріал, з якого формують вуглецеві заготовки). В даній роботі було розглянуто турбулентний потік степеневої рідини та рідин Бінгама та Гершеля-Балклі, запропоновано використання моделі осередненої ефективної молекулярної в’язкості для степеневої рідини в області розвиненої турбулентності. Недоліком такої моделі в плані використання іiі для моделювання формування вуглецевих виробів є припущення про турбулентність потоку, адже пресування проходить досить повільно (швидкість плунжера 0,3-0,5 м/хв.).

Порівнянню реологічних моделей не ньютонівських речовин присвячена робота [9], в якій порівнюється моделі тертя Воелмі та в’язкопластичних речовин Бінгама. Дані окремо взяті моделі можуть використовуватись в моделюванні процесу формування для опису реологічних властивостей електродної маси, але самі по собі вони не описують рух потоку та розподіл енергії, тому мають бути доповнені. 
В роботі [10] обгрунтовано необхідність врахування ефекту пристінного ковзання для випадку екструзії високов'язких матеріалів. Даний ефект має бути врахований при моделюванні процесу формування, оскільки електродна маса є в'язкопластичною рідиною з доволі високою в'язкістю.

Автори [11] розробили дослідну установку, що дає змогу проводити вимірювання ефективної динамічної в'язкості композитних матеріалів на основі пеку та термообробленої вуглецевої сировини та визначили температурні залежності динамічної в'язкості різних за складом вуглецевих композицій, що можуть бути використано при моделюванні процесу формування.

В одній з небагатьох праць, присвячених питанню моделюванню процесу формування саме вуглецевих виробів представлено модель екструзії в'язко-пластичної вуглецевої маси [12], адекватність якої була доведена в цій же роботі, а похибка не перевищувала 4-6\%. Оскільки серед всіх розглянутих моделей дана модель єдина доволі точно описує саме процес формування вуглецевих виробів доцільним $є$ іії використання в подальших дослідженнях.

Поза увагою авторів наведених вище робіт залишається дослідження впливу таких технологічних параметрів, як потужність нагрівачів, температура завантаженої маси та швидкості пресування на температурні поля робочого простору мундштука гідравлічного пресу, хоча для синтезу системи керування даним процесом таке дослідження $\epsilon$ досить актуальним.

\section{Мета і завдання дослідження}

Метою цього дослідження є дослідження впливу таких технологічних параметрів, як потужність нагрівачів, температура завантаженої маси та швидкості пресування на температурні поля за допомогою числової моделі процесу, створеної на основі математичної моделі [12].

\section{Методи та матеріали досліджень}

В даній праці було досліджено зміну температурного поля в залежності від таких технологічних параметрів: потужності індукторів формувальної та калібрувальної зони мундштука, свічок для додаткового нагріву мундштука, температури поверхні масного циліндру та швидкості пресування. Послідовність технологічних режимів та тривалість моделювання при даних режимах наведено в таблиці 1. При моделюванні зроблено наступне допущення: для дослідження динаміки об'єкту при власне пресуванні вважається можливим безперервне формування виробів, хоча насправді тривалість пресування завжди скінченна і визначається завантаженням пресу. Таке припущення зроблено тому, що перехідні процеси в мундштуці та електродній масі мають досить значну інерційність і для того, щоб дослідити їх необхідно проводити моделювання доволі значного проміжку часу, що перевищує час справжнього пресування.

Таблиця 1 - Технологічні режими, що використовувались в дослідженні

\begin{tabular}{|c|c|c|c|c|c|c|}
\hline $\begin{array}{c}\text { № } \\
\text { П/п }\end{array}$ & $\begin{array}{c}\text { Швидкість } \\
\text { пресуванн, } \mathrm{м/c}\end{array}$ & $\begin{array}{c}\text { Потужність } \\
\text { індуктора } \\
\text { формувальної } \\
\text { зони, Вт }\end{array}$ & $\begin{array}{c}\text { Потужність } \\
\text { індуктора } \\
\text { калібрувально } \\
\text { із зони, Вт }\end{array}$ & $\begin{array}{c}\text { Потужність свічок } \\
\text { для додаткового } \\
\text { нагріву кутів } \\
\text { калібрувальної } \\
\text { зони, Вт }\end{array}$ & $\begin{array}{c}\text { Температура } \\
\text { поверхні масного } \\
\text { циліндра, }{ }^{\circ} \mathrm{C}\end{array}$ & $\begin{array}{c}\text { Тривалість } \\
\text { моделюван } \\
\text { ня, хв }\end{array}$ \\
\hline 1 & $\begin{array}{c}\text { (режим пресування) } \\
0.00033\end{array}$ & 0 & 0 & 0 & 100 & 100 \\
\hline 2 & 0.00033 & 15000 & 15000 & 2000 & 100 & 100 \\
\hline 3 & 0.00033 & 15000 & 15000 & 4000 & 100 & 100 \\
\hline 4 & 0.00033 & 15000 & 30000 & 4000 & 100 & 100 \\
\hline 5 & 0.00033 & 30000 & 30000 & 4000 & 100 & 100 \\
\hline 6 & 0.00033 & 0 & 0 & 0 & 110 & 100 \\
\hline 7 & 0.00033 & 15000 & 15000 & 2000 & 110 & 100 \\
\hline 8 & 0.00033 & 15000 & 15000 & 4000 & 110 & 100 \\
\hline 9 & 0.00033 & 15000 & 30000 & 4000 & 110 & 100 \\
\hline 10 & 0.00033 & 30000 & 30000 & 4000 & 110 & 100 \\
\hline 11 & 0.00053 & 0 & 0 & 0 & 100 & 100 \\
\hline 12 & 0.00053 & 15000 & 15000 & 2000 & 100 & 100 \\
\hline 13 & 0.00053 & 15000 & 15000 & 4000 & 100 & 100 \\
\hline 14 & 0.00053 & 15000 & 30000 & 4000 & 100 & 100 \\
\hline 15 & 0.00053 & 30000 & 30000 & 4000 & 100 & 100 \\
\hline
\end{tabular}


Оскільки для отримання бездефектної продукції необхідно, щоб кожен з нагрівачів забезпечував заданий (такий, що забезпечить умови проковзування) розподіл температур в своїй зоні мундштука, то доцільним буде дослідити також динаміку температур в точках, що характеризують розподіл температур в кінці кожної зони (переріз наприкінці калібрувальної зони - I переріз, переріз на межі формувальна - калібрувальна зона - II переріз, переріз на межі масний циліндр - формувальна зона - III переріз). Положення даних точок зображено на рис.1,2.

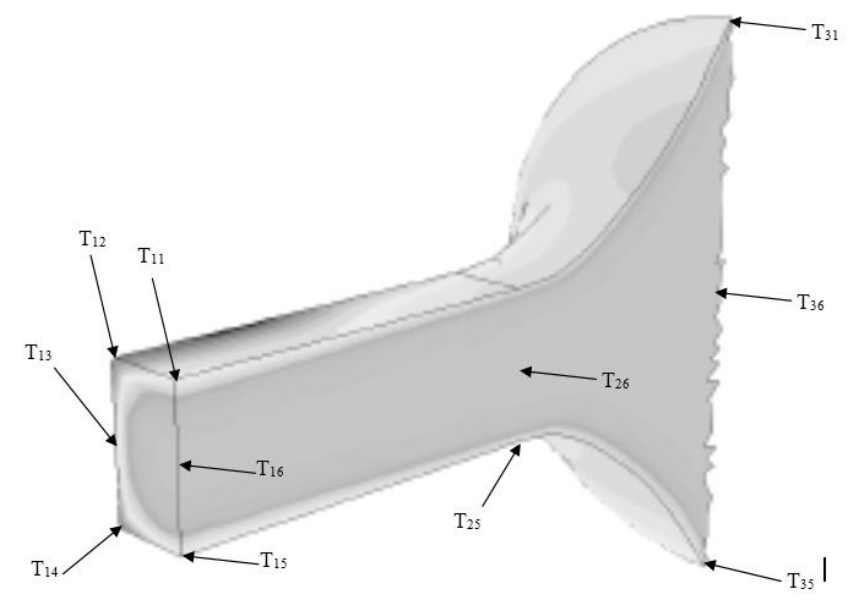

Рис. 1 - Точки, що характеризують розподіл температур в кінці калібрувальної, формувальної зон мундштука та масного циліндра

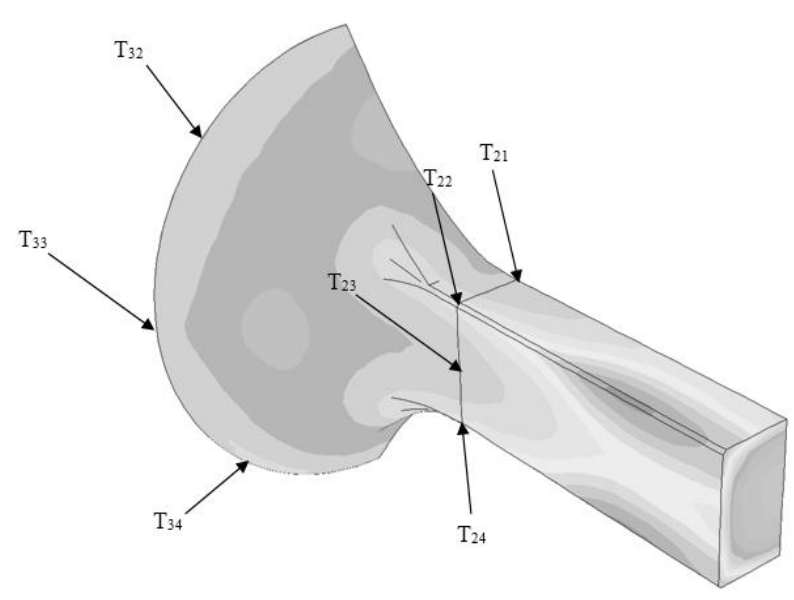

Рис. 2 - Точки, що характеризують розподіл температур в кінці калібрувальної, формувальної зон мундштука та масного циліндра

\section{Результати досліджень та їх обговорення}

Температурне поле в режимі пресування зі швидкістю 0,00033 м/с за температури масного циліндру $100{ }^{\circ} \mathrm{C}$

В даному пункті було досліджено температурні поля при моделюванні режимів 1-5 (табл.1.).

3 початком роботи режиму пресування в умовах відсутності нагріву мундштука (режим №1) відбувається інтенсивне охолодження мундштука й електродної маси. Область мундштука біля індуктора формувальної зони охолоджується нижче температури електродної маси, що пояснюється теплообміном 3 навколишнім середовищем. Наприкінці режиму №11 температура в усьому об’ємі електродної маси в значній мірі усереднюється та становить 95 - $115^{\circ} \mathrm{C}$. Температура в I перерізі перші 15 хв. різко зростає, що спричинено переміщенням більш гарячої електродної маси, що знаходиться між I та II перерізом до I перерізу. Надалі температура в I перерізі починає зменшуватись зі швидкістю в середньому $0,12^{\circ} \mathrm{C} /$ хв.. Температура ж в II перерізі поступово спадає на $17-18{ }^{\circ} \mathrm{C}$ за 100 хв., а в III перерізі на $11-12^{\circ} \mathrm{C}$ за 100 хв.

В результаті вмикання всіх нагрівачів значно зростає температура в зоні біля калібрувального нагрівача. Температура в перерізі I починає зростати. Приріст температури склав $3-7^{\circ} \mathrm{C}$. Швидкість зростання температури в точках $\mathrm{T}_{12}, \mathrm{~T}_{14}$ поступово зменшується (рис.4. (а)), що свідчить про малу інерційність. Після перших 25-30 хв. нагріву 
температура в перерізі II починає зростати зі швидкістю $0,02-0,04{ }^{\circ} \mathrm{C} / \mathrm{Xв}$. В перерізі III температура також починає зростати $\left(4,5-6,5^{\circ} \mathrm{C}\right.$ за 100 хв.), при цьому швидкість зростання поступово зменшується, що свідчить про малу інерційність (рис.4. (в)).

При подальшому моделюванні зі збільшеною потужністю свічок для додаткового нагріву кутів калібрувальної зони (режим №3) було виявлено значне зростання температури лише в області, що знаходиться безпосередньо близько до свічок. Найбільше зросла температура в I перерізі $\left(6-13^{\circ} \mathrm{C}\right.$ за 100 хв.) (рис.4. (а)). Швидкість нагріву в II перерізі зменшується до $0,017-0,03^{\circ} \mathrm{C} /$ хв. (рис.4. (б)). При детальному аналізі результатів було виявлено, що зменшення швидкості спричинено виходом перехідної характеристики на усталений рівень, тому можна стверджувати, що збільшення потужності свічок не впливає на температуру в II перерізі. Температура ж в III перерізі зростає на $1-1,5^{\circ} \mathrm{C}$ за 100 хв. Така зміна спричинена поступовим виходом перехідної характеристики на новий рівень i свідчить про незалежність температури в III перерізі від потужності свічок (рис.4 (в)).

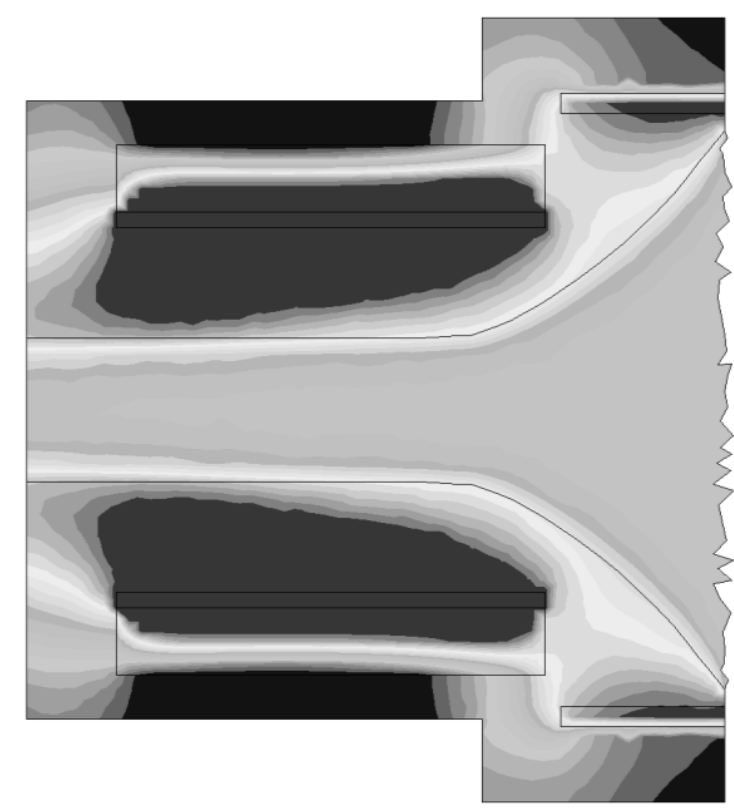

Рис. 3 - Температурне поле наприкінці технологічного режиму №5

Збільшення потужності індуктора калібрувальної зони (режим №4) призвело до значного збільшення температури мундштука біля індуктора калібрувальної зони. В перерізі I швидкість зростання температури збільшується після перших 25 хв. моделювання і складає $0,07-0,075$ C/хв. Така зміна свідчить про наявність зв’язку між потужністю індуктора калібрувальної зони і температурою в перерізі I (рис.4. (а)) та про наявність транспортного запізнювання. Швидкість зміни температури в II перерізі перші 25-30 хв. не змінюється в порівнянні з попереднім режимом, але потім зростає до $0,05-0,08^{\circ} \mathrm{C} /$ хв. (рис.4. (б)). В III перерізі температура зростає на $0,5^{\circ} \mathrm{C}$, аналіз отриманих результатів показав незалежність температури в III перерізі від потужності індуктора калібрувальної зони.

Моделювання зі збільшеною потужністю індуктора формувальної зони виявило (режим №5) значне зростання температури зони мундштука між індукторами формувальної та калібрувальної зони та електродної маси, що знаходиться близько до поверхні формувальної зони мундштука (рис. 3). Приріст температури в I перерізі зменшується до $5-7^{\circ} \mathrm{C}$ за 100 хв. (рис. 4 (а)), характер зміни температури в даному перерізі дає змогу зробити висновок про незалежність температури в I перерізі від потужності індуктора формувальної зони. Після перших 20 хв. моделювання швидкість зміни температури в II перерізі незначно збільшується з $0,03-0,05^{\circ} \mathrm{C} / \mathrm{xв}$. до $0,05-0,06^{\circ} \mathrm{C} / \mathrm{xв}$, що може свідчити про появу впливу потужності індуктора формувальної зони на температуру в цьому перерізі. Це означає, що зміна швидкості пресування впливає також на зв'язок між температурою в II перерізі та потужністю індуктора формувальної зони. Найбільше зросла температура в III перерізі (7,5 - $10^{\circ} \mathrm{C}$ за 100 хв.) (рис.4. (в)). При цьому динаміка температури свідчить про досить швидку реакцію температури в цьому перерізі на зміну саме потужності індуктора формувальної зони. 


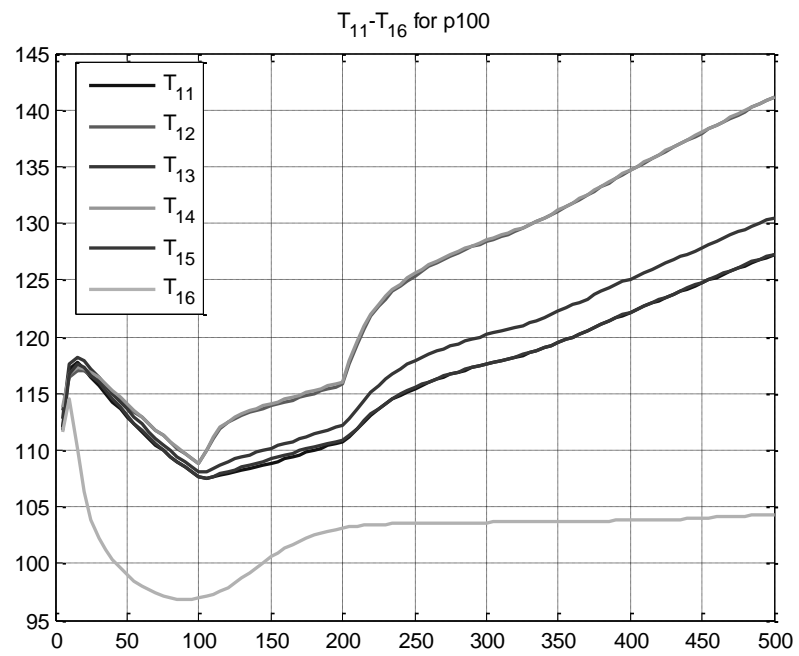

a)

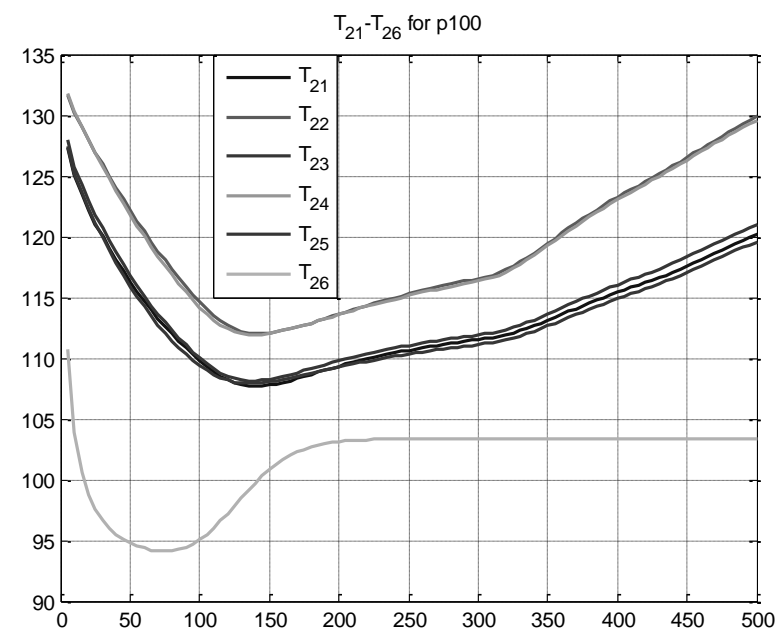

б)

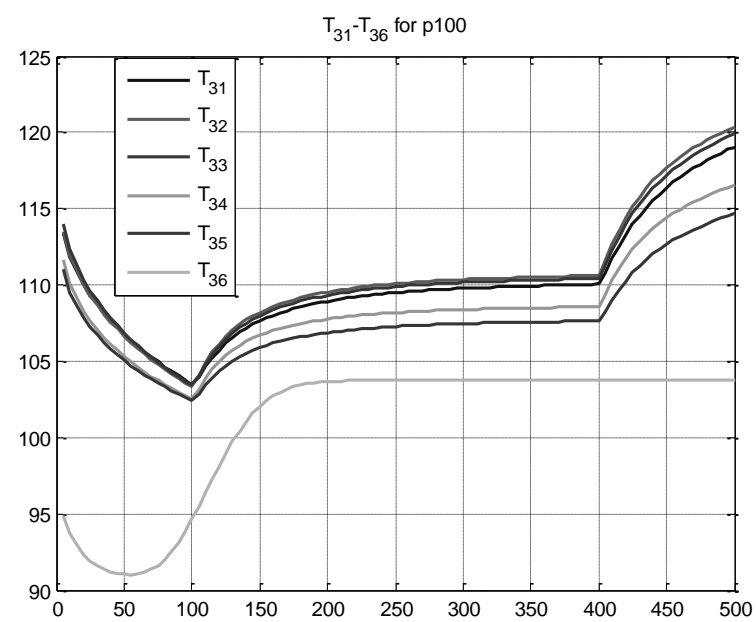

B)

(а) - I переріз, (б) - II переріз, (в) - III переріз

Рис. 4 - Динаміка температури в контрольних точках

Температурне поле в режимі пресування зі швидкістю 0,00033 м/с за температури масного циліндру $110{ }^{\circ} \mathrm{C}$

Дане дослідження включає в себе аналіз результатів моделювання режимів №6 - 10 (табл.1.).

Зі збільшенням температури масного циліндру в умовах відсутності нагріву мундштука (режим №6) відбувається інтенсивне охолодження мундштука й електродної маси. Область мундштука біля індуктора формувальної зони так само як і в п.3.4 охолоджується нижче температури електродної маси.

На відміну від режиму підготовки в режимі пресування зміна температури масного циліндру впливає на динаміку температури не лише в формувальній зоні мундштука, а й в усьому його об'ємі.

Наприкінці режиму №6 температура в усьому об’ємі електродної маси в значній мірі усереднюється та становить $95-115^{\circ} \mathrm{C}$. Температура в I перерізі знову росте перших 15 хв., після чого починає різко спадати зі швидкістю $0,12{ }^{\circ} \mathrm{C}$ / хв., що відповідає швидкості в режимі №1.

Температура ж в II перерізі поступово спадає на $17-18{ }^{\circ} \mathrm{C}$ за 100 хв., а в III перерізі на $6-7{ }^{\circ} \mathrm{C}$ за 100 хв., що на $5{ }^{\circ} \mathrm{C}$ менше ніж в режимі №1. Таким чином для режиму №6 справедливим є твердження лише про наявність значного впливу зміни температури масного циліндру на температури в III перерізі та формувальній зоні мундштука. Відсутність значного впливу на весь інший об'єм пояснюється великою інерційністю реакції на зміну температури масного циліндру, що є наслідком геометричних особливостей мундштука. Так чи інакше при моделюванні наступних режимів наявність впливу зміни температури масного циліндра на температурні поля в усьому об'ємі мундштука стає очевидною. 
Температура в точках $\mathrm{T}_{16}, \mathrm{~T}_{26}, \mathrm{~T}_{36}$ зростає до $104-105^{\circ} \mathrm{C}$ (рис.6), тоді, як в попередньому дослідженні температура в даних точках встановлюється на рівні 103,5 - 104,5 ${ }^{\circ} \mathrm{C}$, що, очевидно $є$ наслідком теплообміну $з$ більш нагрітими шарами електродної маси.

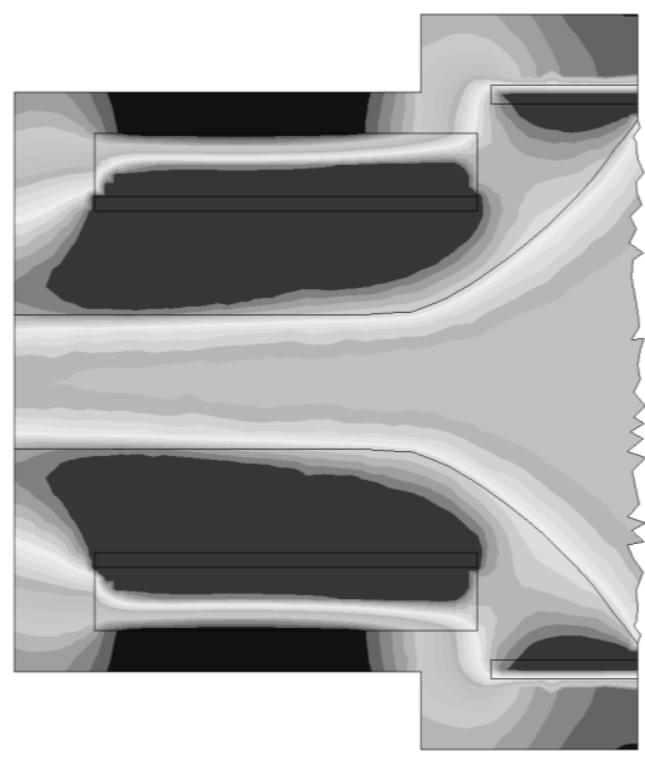

Рис. 5 - Температурне поле наприкінці технологічного режиму №10

В результаті вмикання всіх нагрівачів (режим №7) значно зростає температура в зоні біля калібрувального нагрівача, мундштука та електродної маси біля індуктора формувальної зони. Температура в перерізі I починає зростати. Приріст температури склав $4,5-8,5^{\circ} \mathrm{C}$ за 100 хв., що вище на $1,5^{\circ} \mathrm{C}$ в порівнянні з режимом №2. Швидкість зростання температури в точках $\mathrm{T}_{12}, \mathrm{~T}_{14}$ поступово зменшується, що свідчить про малу інерційність. Після перших 2530 хв. нагріву температура в перерізі II починає зростати 3 швидкістю $0,03-0,05{ }^{\circ} \mathrm{C} /$ хв. що вище на $0,01{ }^{\circ} \mathrm{C} /$ хв. в порівнянні з режимом №2. В перерізі III температура також починає зростати $\left(5-7^{\circ} \mathrm{C}\right.$ за 100 хв., що також вище на $0,5^{\circ} \mathrm{C}$ в порівнянні з режимом №2), при цьому швидкість зростання поступово зменшується, що свідчить про малу інерційність (рис.6. (в)).

При подальшому моделюванні зі збільшеною потужністю свічок для додаткового нагріву кутів калібрувальної зони (режим №8) найбільше зростання температури виявлено в області, що знаходиться безпосередньо близько до свічок. Температура в I перерізі зросла на $8-13{ }^{\circ} \mathrm{C}$ за 100 хв. (рис.6. (а)). В точках $\mathrm{T}_{11}, \mathrm{~T}_{13}, \mathrm{~T}_{15}$ приріст температури збільшився в порівнянні 3 режимом №3 на $1,5{ }^{\circ} \mathrm{C}$. Швидкість нагріву в II перерізі зменшується до $0,027-0,04^{\circ} \mathrm{C} /$ хв. (рис.6. (б)), що знову таки більше ніж в режимі №13 на $0,01{ }^{\circ} \mathrm{C} /$ хв. Температура ж в III перерізі зростає на $1-1,5^{\circ} \mathrm{C}$ за 100 хв.

Збільшення потужності індуктора калібрувальної зони (режим №9) призвело до значного збільшення температури мундштука біля індуктора калібрувальної зони. В перерізі I швидкість приросту збільшується після перших 25 хв. моделювання і складає $0,06-0,08^{\circ} \mathrm{C} /$ хв. (рис.6. (а)), що більше за швидкість в режимі №4 на $0,005{ }^{\circ} \mathrm{C} /$ хв. Швидкість зміни температури в II перерізі перші 25-30 хв. не змінюється в порівнянні з попереднім режимом, але потім зростає до $0,06-0,09^{\circ} \mathrm{C} /$ хв. (рис.6. (б)), що на $0,01{ }^{\circ} \mathrm{C} /$ хв. більше ніж швидкість в режимі №14. В III перерізі температура зростає на $0,5^{\circ} \mathrm{C}$, що підтверджує незалежність температури в III перерізі від потужності індуктора калібрувальної зони.

Аналіз результатів моделювання зі збільшеною потужністю індуктора формувальної зони (режим №10) виявив значне зростання температури зони мундштука між індукторами формувальної та калібрувальної зони та електродної маси, що знаходиться близько до поверхні формувальної зони мундштука (рис.5.). Приріст температури в I перерізі зменшується до $5-7^{\circ} \mathrm{C}$ за 100 хв. (рис.6. (а)). Швидкість зміни температури в II перерізі зменшується до 0,05$0,08{ }^{\circ} \mathrm{C} /$ хв., що на $0,01-0,02{ }^{\circ} \mathrm{C} /$ хв. більше ніж в режимі №5. Найбільше зросла температура в III перерізі $\left(8-10^{\circ} \mathrm{C}\right.$ за 100 хв.) (рис.6. (в)). 


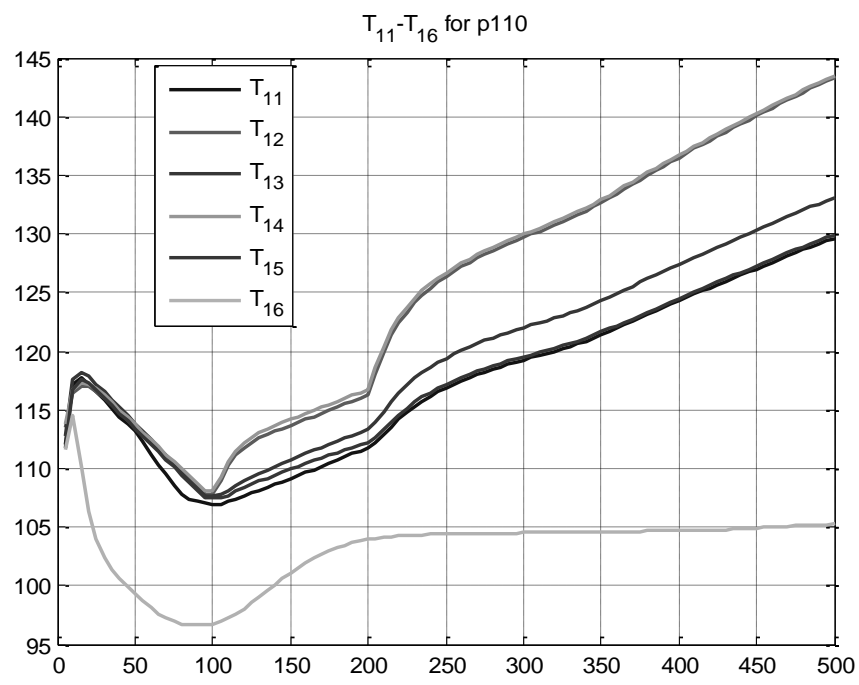

a)

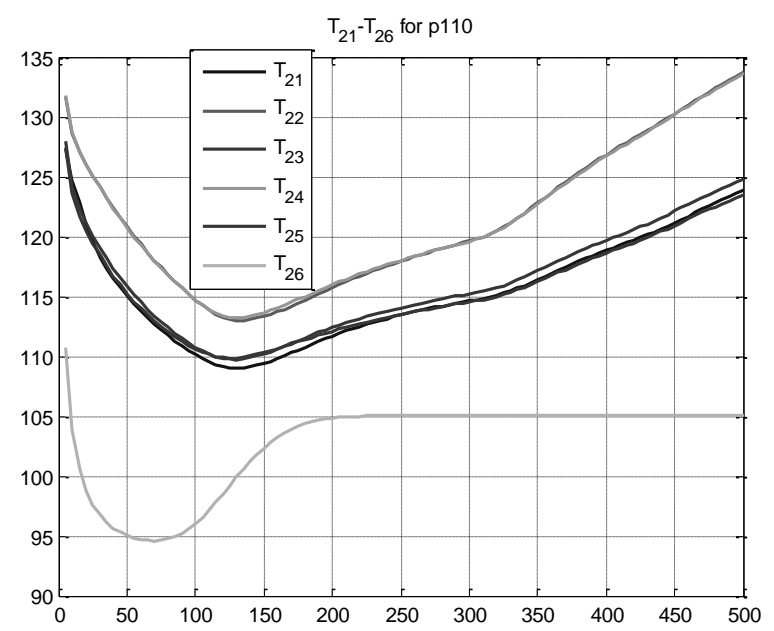

б)

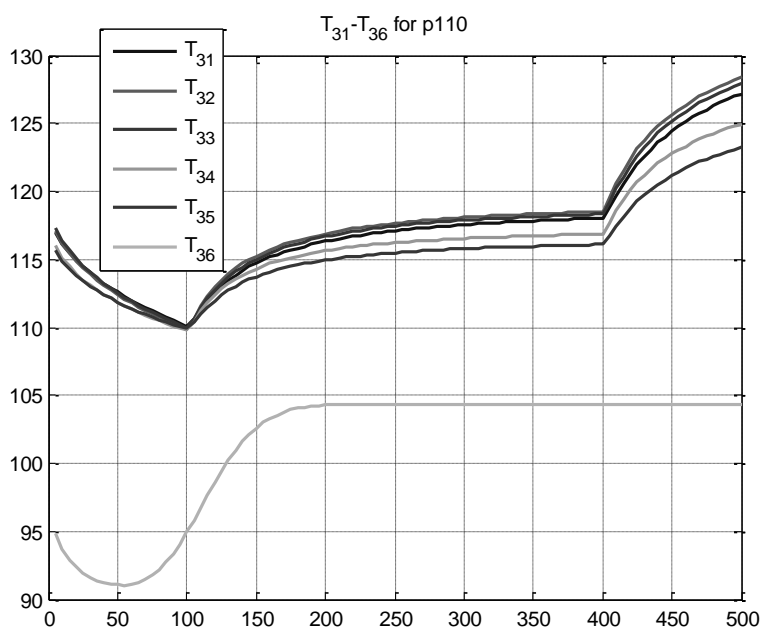

B)

(a) - I переріз, (б) - II переріз, (в) - III переріз

Рис. 6 - Динаміка температури в контрольних точках

Загалом, наприкінці даного дослідження різниця з результатами попереднього дослідження склала 0,6 - 9,3 ${ }^{\circ} \mathrm{C}$, що свідчить про значний вплив температури масного циліндра на температурні поля мундштука в режимі пресування.

Температурне поле в режимі пресування зі швидкістю 0,00053 м/с за температури масного циліндру $100{ }^{\circ} \mathrm{C}$

Дане дослідження включає в себе аналіз результатів моделювання режимів №11 - 15 (табл.1.).

Зі збільшенням швидкості пресування в умовах відсутності нагріву мундштука (режим №11) відбувається інтенсивне охолодження мундштука й електродної маси. В порівнянні 3 дослідженням режиму пресування зі швидкістю 0,00033 м/с в даному дослідженні температури в об'ємі електродної маси більші, в той час, як температури в об'ємі самого мундштука менші (рис.7, 8). Це пояснюється тим, що збільшення швидкості пресування спричинює ріст інтенсивності теплообміну між більш нагрітою поверхнею мундштука та менш нагрітим об'ємом електродної маси. Наприкінці режиму №11 температура в усьому об’ємі електродної маси в значній мірі усереднюється та становить $95-116{ }^{\circ} \mathrm{C}$. Температура в I перерізі знову росте перших 15 хв., після чого починає різко спадати зі швидкістю $0,08^{\circ} \mathrm{C} / \mathrm{xв}$., що на 0,04 менше ніж в режимі №1. Це знову таки пояснюється інтенсивнішим теплообміном 3 поверхнею мундштука. Температура ж в II перерізі поступово спадає на $16-17,5^{\circ} \mathrm{C}$ за 100 хв., а в III перерізі на 6-7 ${ }^{\circ} \mathrm{C}$ за 100 хв., що на $1{ }^{\circ} \mathrm{C}$ та $5{ }^{\circ} \mathrm{C}$ відповідно менше ніж в режимі №11. Таким чином для режиму №11 справедливим є твердження про наявність значного впливу зміни швидкості пресування на температури в усьому об’ємі мундштука та 
електродної маси, що також дає змогу зробити висновки про доволі швидку реакцію на зміну швидкості пресування. Температура в точках $\mathrm{T}_{16}, \mathrm{~T}_{26}, \mathrm{~T}_{36}$ зростає до $104-107{ }^{\circ} \mathrm{C}$, тоді, як в дослідженні температура в даних точках встановлюється на рівні $103,5-104,5^{\circ} \mathrm{C}$.

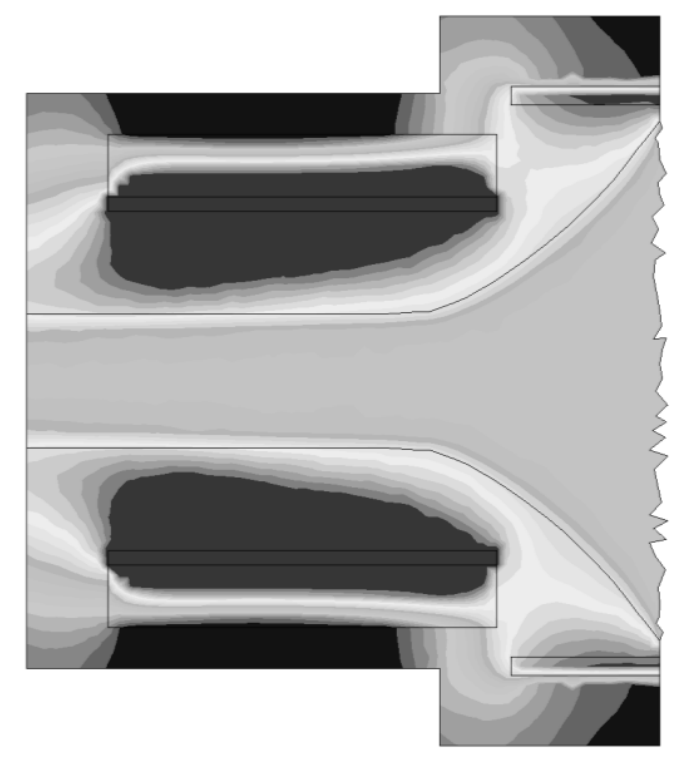

Рис. 7 - Температурне поле наприкінці технологічного режиму №15

В результаті вмикання всіх нагрівачів (режим №12) значно зростає температура в зоні біля калібрувального нагрівача, мундштука та електродної маси біля індуктора формувальної зони. Температура в перерізі I починає зростати. Приріст температури склав $4-8^{\circ} \mathrm{C}$ за 100 хв., що вище на $1{ }^{\circ} \mathrm{C}$ в порівнянні з режимом №2. Швидкість зростання температури в точках $\mathrm{T}_{12}, \mathrm{~T}_{14}$ поступово зменшується (рис.8. (а)), що свідчить про малу інерційність. Після перших 25-30 хв. нагріву температура в перерізі II починає зростати з швидкістю 0,05-0,06 ${ }^{\circ} \mathrm{C} / \mathrm{xв}$. що вище на 0,01 $0,02{ }^{\circ} \mathrm{C} /$ хв. в порівнянні з режимом №2. В перерізі ІІІ температура також починає зростати $\left(5,5-7,5^{\circ} \mathrm{C}\right.$ за 100 хв., що також вище на $1{ }^{\circ} \mathrm{C}$ в порівнянні з режимом №12) (рис.8. (в)).

При подальшому моделюванні зі збільшеною потужністю свічок для додаткового нагріву кутів калібрувальної зони (режим №13) найбільше зростання температури виявлено в області, що знаходиться безпосередньо близько до свічок. Температура в I перерізі зросла на $9-14{ }^{\circ} \mathrm{C}$ за 100 хв. (рис.8. (а)), що більше в порівнянні 3 режимом №3 на 2 ${ }^{\circ} \mathrm{C}$. Швидкість нагріву в II перерізі зменшується до $0,033-0,043^{\circ} \mathrm{C} /$ хв. (рис.8. (б)), що знову таки більше ніж в режимі №3 на $0,016^{\circ} \mathrm{C} /$ хв. Температура ж в III перерізі зростає на $1-1,5^{\circ} \mathrm{C}$ за 100 хв.

Збільшення потужності індуктора калібрувальної зони (режим №14) призвело до значного збільшення температури мундштука біля індуктора калібрувальної зони. В перерізі I швидкість приросту збільшується після перших 25 хв. моделювання і складає $0,07-0,09{ }^{\circ} \mathrm{C} /$ хв. (рис.8. (а)), що більше за швидкість в режимі №4 на $0,0015{ }^{\circ} \mathrm{C} /$ хв. Швидкість зміни температури в II перерізі перші 25-30 хв. не змінюється в порівнянні з попереднім режимом, але потім зростає до $0,06-0,09^{\circ} \mathrm{C} /$ хв. (рис.8. (б)), що на $0,01{ }^{\circ} \mathrm{C} /$ хв. більше ніж швидкість в режимі №14. В III перерізі температура зростає на $0,5^{\circ} \mathrm{C}$, що підтверджує незалежність температури в III перерізі від потужності індуктора калібрувальної зони.

Моделювання зі збільшеною потужністю індуктора формувальної зони (режим №15) виявило значне зростання температури зони мундштука між індукторами формувальної та калібрувальної зони та електродної маси, що знаходиться близько до поверхні формувальної зони мундштука (рис.7.) Приріст температури в I перерізі зменшується до $5-7^{\circ} \mathrm{C}$ за 100 хв. (рис.8. (а)). Швидкість зміни температури в II перерізі зменшується до $0,05-0,08{ }^{\circ} \mathrm{C} / \mathrm{xв.,} \mathrm{що} \mathrm{на}$ $0,01-0,02{ }^{\circ} \mathrm{C} /$ хв. більше ніж в режимі №5. Найбільше зросла температура в III перерізі $\left(8-10^{\circ} \mathrm{C}\right.$ за 100 хв.) (рис.8. (в)).

Загалом, наприкінці даного дослідження різниця з результатами дослідження склала $1,9-8,1{ }^{\circ} \mathrm{C}$, що свідчить про значний вплив швидкості пресування на температурні поля мундштука в режимі пресування.

Варто також зазначити, що збільшення швидкості пресування призвело до збільшення градієнту температур в електродній масі, що має бути враховано при розробці систем керування. 

http://www.atbp.onaft.edu.ua/



a)

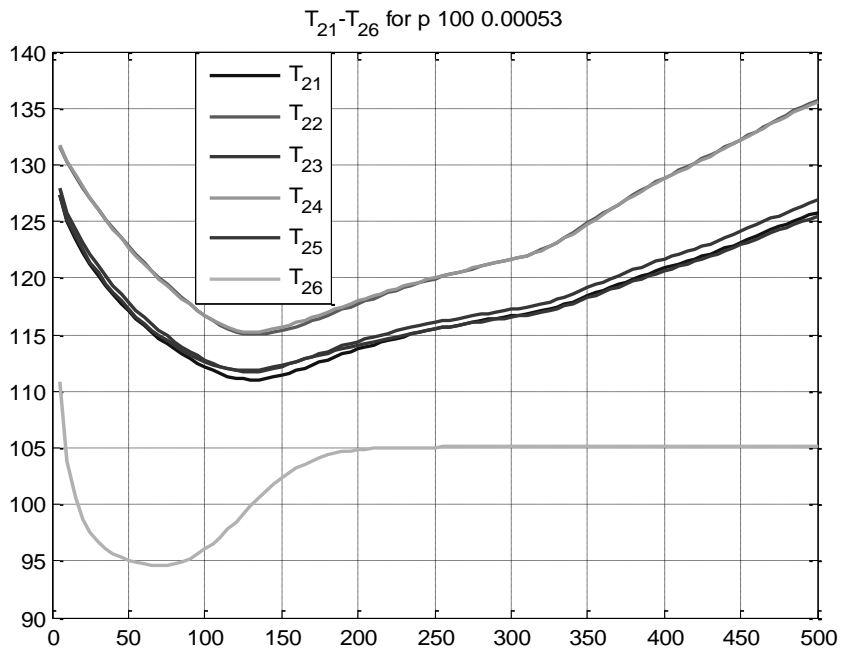

б)

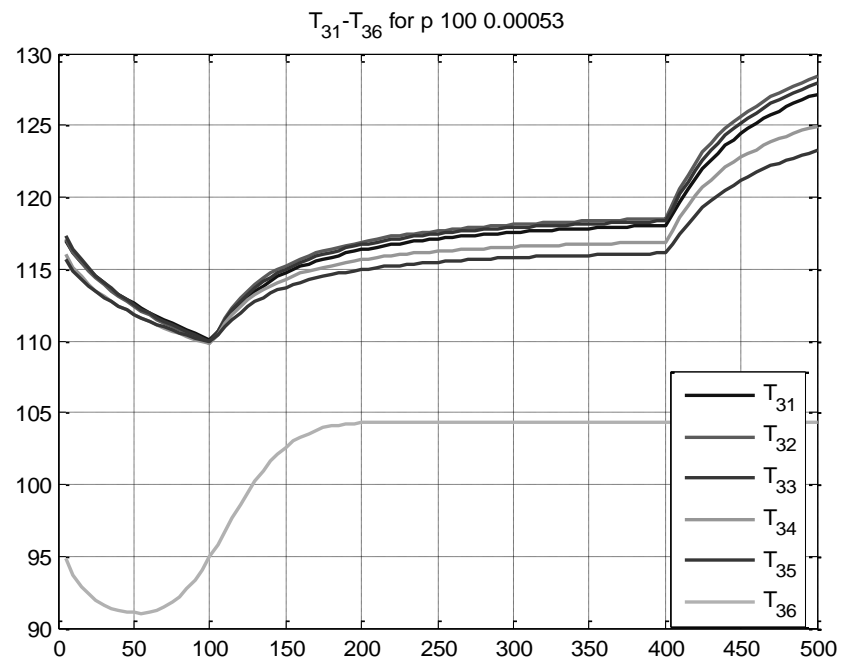

в)

(a) - I переріз, (б) - II переріз, (в) - III переріз

Рис. 6 - Динаміка температури в контрольних точках 
http://www.atbp.onaft.edu.ua/

\section{Висновки}

Підвищення ефективності процесу формування вуглецевих виробів тісно пов'язане з розвитком наукових уявлень про процеси, що протікають в мундштуці та дослідженнями даного процесу за допомогою математичних моделей.

Аналіз існуючих досліджень процесу показав відсутність дослідження впливу технологічних параметрів на температурні поля мундштука гідравлічного пресу. Тому, для проведення даного дослідження, на основі математичної моделі [12] було розроблено числову модель процесу.

В результаті досліджень, проведених за допомогою розробленої моделі виявлено, що найбільший вплив на температури в зонах I-II має індуктор калібрувальної зони. Також індуктор формувальної зони має значний вплив на температурне поле в III та II зонах, а свічки на температури в I та II зоні. При цьому вплив нагрівачів на більш віддалені зони проявляється тільки за 20-30 хв. після зміни потужності нагрівача, що свідчить про появу запізнювання в перехідному процесі.

Температура завантаженої маси має досить значний вплив на розподіл температур в усьому об'ємі робочого простору мундштука. Також виявлено, що збільшення швидкості пресування негативно впливає на середню температуру електродної маси, а також збільшує градієнт температур від центральної частини робочого простору мундштука до його меж.

Отримані результати можуть бути використані для розробки більш ефективних регламентів виробництва та можуть бути враховані при розробці нових систем керування даним процесом.

\section{Список використаних джерел}

[1] Чалых А.Ф., Соседов В.П. Графитация углеродистых материалов. М.: Металлургия, 1987. 176 с.

[2] Санников А. К., Сомов А. Б., Ключников В. В. Производство электродной продукции. М.: Металлургия, 1985. $129 \mathrm{c.}$

[3] Раувендаль К. Экструзия полимеров. СПб.: Профессия, 2006. 768 с.

[4] Торнер Р. В. Теоретические основы переработки полимеров. М.: Химия, 1977. 464 с.

[5] Tadmor Z. Principles of Polymer Processing. N.-Y.: Wiley-Interscience, 2006. 961 p.

[6] Галыгин В.Е., Баронин Г.С., Таров В.П., Завражин Д.О. Современные технологии получения и переработки полимерных и композиционных материалов: учебное пособие. Тамбов: Изд-во ФГБОУ ВПО «ТГТУ», 2012.180 c.

[7] Василенко В.Н., Остриков А.Н., Ряжских В.И. Математическая модель течения двух вязкопластичных сред в формующем канале экструдера при коэкструзии. Вестник ВГУИТ. 2012. № 2. С. 64 - 67.

[8] Гаврилов, А.А. Математическая модель и численная методика моделирования развитого турбулентного течения неньютоновских вязкопластических жидкостей / Гаврилов А.А., Минаков А.В., Дектерев А.А., Рудяк В.Я. // Тезисы докладов международной конференции «Современные проблемы прикладной математики и механики: теория, эксперимент и практика», посвященная 90-летию со дня рождения академика Н.Н. Яненко. — 2011. C. $85-86$

[9] Chalk, C, Borman, D, Sleigh, PA et al. (3 more authors) (Accepted: 2017) A numerical comparison of a frictional and viscoplastic debris flow model. In: to be confirmed. 19th International Conference on Soil Mechanics and Geotechnical Engineering, 17-22 Sep 2017, Seoul, South Korea.

[10] Сівецький В.І., Сокольський О.Л., Бурла Ю.В. Дослідження процесу екструзійного формування полімерів 3 урахуванням ефекту пристінного ковзання. Вісник НТУУ “КПІ”. Хімічна інженерія, екологія та ресурсозбереження. 2009. №1. С. 17-21.

[11] Карвацький А. Я. Реологічні властивості вуглецевих композицій в діапазоні температури $120-170{ }^{\circ} \mathrm{C} / \mathrm{A}$. Я. Карвацький, Т. В. Лазарєв, Д. Г. Швачко, О. С. Тищенко // Вісник Національного технічного університету "Харківський політехнічний інститут". Серія : Нові рішення в сучасних технологіях. - 2016. - № 18. - С. 74-79.

[12] Лазарев Т. В. Математическая модель процесса экструзии вязко-пластичной углеродной массы / Т. В. Лазарев, А. Я. Карвацкий, С. В. Лелека, А. Ю. Педченко // Вісник Національного технічного університету "Харківський політехнічний інститут". Серія : Нові рішення в сучасних технологіях. - 2016. - № 12. - С. 31-37.

\section{References}

[1] Chalyh A.F., Sosedov V.P. Grafitacija uglerodistyh materialov. Moscow, Metallurgija Publ., 1987. 176 p.

[2] Sannikov A. K., Somov A.B, Kliuchnikov V.V. Proizvodstvo elektrodnoi produktsii. Moscow, Metallurgija Publ., 1985. $129 \mathrm{p}$.

[3] Rauvendal K. Ekstruziya polimerov. SPb.: Professiya Publ., 2006. 768 p.

[4] Torner R. V. Teoreticheskie osnovyi pererabotki polimerov. M.: Himiya Publ., 1977. 464 p.

[5] Tadmor Z. Principles of Polymer Processing. N.-Y.: Wiley-Interscience, 2006. 961 p.

[6] Galyigin V.E., Baronin G.S., Tarov V.P., Zavrazhin D.O. Sovremennyie tehnologii polucheniya i pererabotki polimernyih i kompozitsionnyih materialov: uchebnoe posobie. Tambov: FGBOU VPO «TGTU» Publ., 2012. 180 p.

[7] Vasilenko V.N., Ostrikov A.N., Ryazhskih V.I. Matematicheskaya model techeniya dvuh vyazkoplastichnyih sred $v$ formuyuschem kanale ekstrudera pri koekstruzii. Vestnik VGUIT. 2012. \# 2. P. 64 - 67.

[8] Gavrilov, A.A. Matematicheskaya model i chislennaya metodika modelirovaniya razvitogo turbulentnogo techeniya nenyutonovskih vyazkoplasticheskih zhidkostey / Gavrilov A.A., Minakov A.V., Dekterev A.A., Rudyak V.Ya. // Tezisyi 
http://www.atbp.onaft.edu.ua/

dokladov mezhdunarodnoy konferentsii «Sovremennyie problemyi prikladnoy matematiki i mehaniki: teoriya, eksperiment i praktika», posvyaschennaya 90-letiyu so dnya rozhdeniya akademika N.N. Yanenko. — 2011. — P. 8586

[9] Chalk, C, Borman, D, Sleigh, PA et al. (3 more authors) (Accepted: 2017) A numerical comparison of a frictional and viscoplastic debris flow model. In: to be confirmed. 19th International Conference on Soil Mechanics and Geotechnical Engineering, 17-22 Sep 2017, Seoul, South Korea

[10] Sivetskiy V.I., Sokolskiy O.L., Burla Yu.V. Doslidzhennya protsesu ekstruzIynogo formuvannya polimeriv $z$ urahuvannyam efektu pristInnogo kovzannya. Visnik NTUU "KPI". Himichna Inzheneriya, ekologiya ta resursozberezhennya. 2009. \#1. P. 17-21.

[11] Karvatskiy A. Ya. Reologichni vlastivosti vugletsevih kompozitsIy $v$ diapazoni temperaturi 120-170 ${ }^{\circ} \mathrm{C} / \mathrm{A} . \mathrm{Ya}^{\mathrm{B}}$ Karvatskiy, T. V. Lazarev, D. G. Shvachko, O. S. Tischenko // Visnik NatsIonalnogo tehnIchnogo unIversitetu "HarkIvskiy polItehnIchniy Institut". SerIya : NovI rIshennya v suchasnih tehnologIyah. - 2016. - \# 18. - p. $74-79$.

[12] Lazarev T. V. Matematicheskaia model' protsessa ekstruzii viazko-plastichnoi uglerodnoi massy / T. V. Lazarev, A. Ia. Karvatskii, S. V. Leleka, A. Iu. Pedchenko // Visnik Natsional'nogo tekhnichnogo universitetu "Kharkivs'kii politekhnichnii institut". Seriia : Novi rishennia v suchasnikh tekhnologiiakh. - 2016. - № 12. - P. 31-37.

\title{
МОДЕЛИРОВАНИЕ БАЛАНСИРОВКИ ЭНЕРГОСИСТЕМЫ ПРИ УСЛОВИИ СОДЕРЖАНИЯ В НЕЙ ЗНАЧИТЕЛЬНОЙ ДОЛИ НЕДИСПЕТЧЕРИЗУЕМЫХ ИСТОЧНИКОВ ЭНЕРГИИ
}

\author{
Максимов М. М. ${ }^{1}$, Давидов В. О. ${ }^{2}$ \\ ${ }^{1,2}$ Одесский национальный политехнический университет, Одесса \\ ORCID: ${ }^{1} 0000-0002-5626-5265,{ }^{2} 0000-0003-3099-7596$ \\ Email: ${ }^{1}$ maximov.agro@gmail.com, ${ }^{2}$ davydov@opu.ua
}

Copyright (C) 2018 by author and the journal "Automation of technological and business - processes. This work is licensed under the Creative Commons Attribution International License (CC BY). http://creativecommons.org/licanses/by/4.0

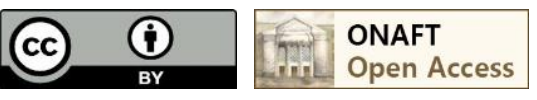

DOI:

\footnotetext{
Аннотация.

Повышение доли недиспетчеризуемых возобновляемых источников энергии в единых энергосистемах влечет за собой проблему балансировки энергосистемы. Как правило, затраты на поддержание баланса между произведенной и потребленной энергией сторонники «зеленой» энергии перекладывают на плечи энергосистемы и не учитывают при подсчете экономического эффекта от возобновляемых источников.

Цель данной работы, провести имитаџионное моделирование процесса балансировки энергосистемь с больщой долей недиспетчеризуемых возобновляемых источников.

В работе проведен анализ пусковых режимов различных типов энергоустановок. Смоделирована энергосистема с различным соотношением диспетчерезуемых энергоустановок. Проведена оценка различных сценариев развития событий при появлении дефицита генерируемой энергии в размере 25\%, 50\% и 75\% от установленной мошности недиспетчерезуемых источников энергии. Показано, что традиционный метод компенсации возмущений за счет вращающчегося резерва при увеличении доли возобновляемых источников не может полностью компенсировать эти возмущения, что на практике приведет к отключению от энергосети части потребителей.

Повышение доли недиспетчеризуемых возобновляемых источников в единой энергетической системе ведет $к$ уменьшению доли обычных энергоустановок, которые потенџиально могут поддерживать баланс.

Нормализовать работу энергосистемы можно путем дублирования мощности недиспетчеризуемых источников эквивалентной мощностью источников с мальм временем пуска, например, дизель-генераторами. Такой подход
} 